\title{
RAGWORT AND NODDING THISTLE CONTROL WITH NOVEL 2,4-D MIXTURES
}

\author{
T. K. JAMES and A. RAHMAN \\ AgResearch, Ruakura Research Centre, Private Bag 3123, Hamilton, \\ New Zealand \\ Corresponding author: trevor.james@agresearch.co.nz
}

\begin{abstract}
For 50 years 2,4-D has been the predominant chemical used for weed control on New Zealand farms but there is regulatory pressure to reduce application rates. Pot and field experiments investigated the efficacy of lower rates of 2,4-D when used in combination with either chlorsulfuron or mesotrione, for control of ragwort (Senecio jacobaea) and nodding thistle (Carduus nutans). Experiments on potted plants evaluated herbicide combinations at several growth stages from small rosettes to pre-bolting while field trials were on weeds at bolting. Ragwort was well controlled by the half-rate of 2,4-D plus either chlorsulfuron or mesotrione. For nodding thistle, mesotrione was a better additive. In the field trials, control of both ragwort and nodding thistle from the halfrate of 2,4-D plus either chlorsulfuron or mesotrione was equal to or significantly better than that from the full-rate of 2,4-D alone. However, in some instances there was also significant pasture damage.
\end{abstract}

Keywords: nodding thistle, Carduus nutans, ragwort, Senecio jacobaea, 2,4-D, mesotrione, chlorsulfuron.

\section{INTRODUCTION}

The herbicide 2,4-D has been used for controlling broad-leaved weeds in New Zealand pastures since 1945 (Ward 1949). It was the first herbicide to show good grass tolerance while controlling most common broad-leaved weeds (Matthews 1956). It was widely researched from 1949-1959 with more than half of all the papers on 2,4-D published in the New Zealand Plant Protection Conference proceedings appearing in this period. During this period there were seven different formulations of 2,4-D available in 30 propriety brands, reflecting the importance of this herbicide at the time (Matthews 1956).

The advantages of the new hormone type herbicides would probably not have been fully realised were it not for the parallel development of precise, low-volume, hydraulic nozzles that allowed more accurate application of pesticides over a wide area (Brodie 1949). However, these sprayers were not suitable for rolling and hill country farms and two formulations were specifically formulated for use in these situations. These were the 2,4-D dust (1\% sodium salt) and the hormonised superphosphate fertiliser $(0.5-1 \%$ 2,4-D) (Muller 1952). With the advent of helicopters, which were better suited for spray application in hill country, and improved ground applicators in the early 1970s these two formulations and their application methods ceased. However, 2,4-D remains the most widely used herbicide in New Zealand's pastoral sector (Manktelow et al. 2005), albeit now with improved formulations with reduced volatility.

2,4-D is effective in controlling many major weeds of pasture, including ragwort (Senecio jacobaea) and nodding thistle (Carduus nutans) (Martin et al. 1986; James et al. 1995). Despite this there is pressure from several sources to reduce the amount of 2,4-D applied to pasture. The Ministry for the Environment has formulated a policy for pesticide risk reduction with reduced pesticide usage one of the aims (Anon. 2002). Also, farmers are wanting to reduce or avoid the use of 2,4-D due to concerns with herbicide drift and off-target damage or because of problems with herbicide resistance 
in the target weed (James et al. 1995). As a result of this, various sulfonylurea herbicides have been evaluated as alternative or combination herbicides for control of ragwort and nodding thistle (Martin et al. 1988; James et al. 1995, 1997). This paper reports on both glasshouse and field investigations of using low rates of sulfonylurea and other herbicides in combination with reduced rates of 2,4-D for control of ragwort and nodding thistle, with the aim of reducing the total amount of herbicide used in pasture.

\section{Field trials}

\section{MATERIALS AND METHODS}

Two field trials were carried out over the summer months of 2006/07 to evaluate the use of certain herbicides below their recommended application rates (spikes) in combination with 2,4-D for the control of ragwort and nodding thistle. The active ingredients used as spikes were chlorsulfuron $\left(\right.$ Glean $\left.^{\circledR}\right)$, flumetsulam (Preside ${ }^{\mathrm{TM}}$ ) and mesotrione (Callisto ${ }^{\mathrm{TM}}$ ). Urea was also used as an inorganic adjuvant in the nodding thistle trial. All spikes and adjuvants were evaluated with the ethylhexyl ester formulation of 2,4-D (Pasture-Kleen ${ }^{\mathrm{TM}}$ ). Chlorsulfuron was also used with the dimethylamine salt formulation $\left(\right.$ Baton $\left.^{\circledR}\right)$ (Tables $\left.1 \& 2\right)$. Both formulations were used alone at the highest recommended rates and at half label rates in combination with the spikes and adjuvants. A lower rate of chlorsulfuron was used in the ragwort trial in an attempt to reduce pasture damage from this mixture. The new herbicide, aminopyralid (Tordon Max ${ }^{\circledR}$ ), was also included for comparison.

Trial 1 was laid down on 26 October 2006 on a property in South Waikato where nodding thistle was the problem weed. Nodding thistle plants ranged from large rosettes to pre-bolting plants (300-500 $\mathrm{mm}$ in diameter). Trial 2 was laid down on 28 November 2006, also in South Waikato, where ragwort was the problem weed. The ragwort plants ranged in size from rosettes to pre-bolting plants (100-300 $\mathrm{mm}$ in diameter). Both trials had a plot size of $3 \times 10 \mathrm{~m}$ with four replicates. All treatments were applied with a $\mathrm{CO}_{2}$ powered back pack sprayer with a $3 \mathrm{~m}$ boom fitted with four TeeJet 11003 nozzles to apply 200 litres/ha at $210 \mathrm{kPa}$. Visual assessments of weed control and damage to ryegrass and clover were carried out at approximately monthly intervals for 3 months after treatment. At the time of the final assessments plant counts of nodding thistle and ragwort were also carried out.

\section{Outdoor pot experiments}

Nodding thistle was planted on 9 May 2007 and ragwort on 7 June 2007. Pregerminated seeds were planted into potting mix (Daltons Premium Mix) in $150 \mathrm{~mm}$ diameter plastic pots and grown outside with regular watering and nutrient supplements. Over the next 5 months, four plants were randomly selected and the treatments applied. All treatments were applied with a $\mathrm{CO}_{2}$ pressurised, moving belt sprayer fitted with a single, even spray nozzle (TeeJet $8003 \mathrm{E}$ ) to apply 200 litres/ha at $210 \mathrm{kPa}$. In an attempt to achieve greater efficacy the rate of chlorsulfuron used in the ragwort pot trial was increased to be the same as used for nodding thistle. The average size of the plants at treatment is presented in Table 1. After treatment the plants were assessed every 2 weeks until they had either died and the crown decayed or they began to regrow.

All the data were subjected to ANOVA to separate treatment means and the LSD was calculated. 
TABLE 1: Average size of potted plants at treatment.

\begin{tabular}{lccllcc}
\hline \multicolumn{2}{c}{ Nodding thistle (planted on 9.5.07) } & & \multicolumn{3}{c}{ Ragwort (planted on 7.6.07) } \\
\cline { 1 - 2 } \cline { 5 - 6 } $\begin{array}{l}\text { Treatment } \\
\text { date }\end{array}$ & No. of leaves & $\begin{array}{c}\text { Diameter } \\
(\mathrm{mm})\end{array}$ & & $\begin{array}{l}\text { Treatment } \\
\text { date }\end{array}$ & No. of leaves & $\begin{array}{c}\text { Diameter } \\
(\mathrm{mm})\end{array}$ \\
\hline 5.6 .07 & $8.8 \pm 1.0^{1}$ & $146 \pm 27$ & & 13.7 .07 & $8.1 \pm 1.8$ & $123 \pm 12$ \\
23.6 .07 & $10.5 \pm 1.2$ & $215 \pm 26$ & & 3.8 .07 & $14.3 \pm 3.8$ & $188 \pm 26$ \\
6.7 .07 & $15.2 \pm 2.3$ & $261 \pm 28$ & & 24.8 .07 & $30.6 \pm 6.7$ & $285 \pm 35$ \\
3.8 .07 & $19.0 \pm 3.6$ & $298 \pm 43$ & & 28.9 .07 & $46.4 \pm 7.5$ & $379 \pm 47$ \\
31.8 .07 & $23.8 \pm 3.9$ & $327 \pm 25$ & & 31.10 .07 & $51.3 \pm 8.8$ & $388 \pm 36$ \\
28.9 .07 & $32.1 \pm 4.0$ & $350 \pm 82$ & & - & - & - \\
\hline
\end{tabular}

${ }^{1} \pm 1$ standard deviation.

\section{RESULTS AND DISCUSSION}

Field trial - nodding thistle

The results for Trial 1 on nodding thistle are presented in Table 2. The large plants in this trial generally were not well controlled with the 2,4-D treatments. Both the ester and amine formulations at full rate only achieved 20-48\% control while the half rate only resulted in slight damage. However, when the half rate of 2,4-D was combined with either chlorsulfuron or mesotrione the level of control was significantly improved over both the half and full rate of 2,4-D alone. Flumetsulam and urea as additives to 2,4-D had little impact on this weed. Aminopyralid, used alone in this trial, resulted in $100 \%$ control of the nodding thistles present at treatment.

TABLE 2: Control of nodding thistle (\% remaining number of nodding thistle plants per plot) and damage to white clover $(\%)$ from herbicide combinations applied on $\mathbf{2 6 . 1 0 . 0 6}$, with measurements made on 21.11.06 (Nov), 18.12.06 (Dec) and 26.1.07 (Jan).

\begin{tabular}{lcccccccc}
\hline & \multicolumn{3}{c}{ Nodding thistle } & & \multicolumn{3}{c}{ White clover } \\
\cline { 2 - 3 } \cline { 7 - 9 } Treatment (rate: g ai/ha) & Nov & Dec & Jan & & Nov & Dec & Jan \\
\hline Untreated & 0 & 0 & 0 & & 0 & 0 & 0 \\
2,4-D ester (1040) & 13 & 15 & 20 & & 8 & 13 & 0 \\
2,4-D ester (2080) & 28 & 20 & 30 & & 13 & 20 & 0 \\
Ester (1040)+chlorsulfuron (4) & 68 & 68 & 69 & & 30 & 33 & 18 \\
Ester (1040)+flumetsulam (20) & 21 & 25 & 24 & & 5 & 0 & 0 \\
Ester (1040)+mesotrione (20) & 68 & 65 & 84 & & 38 & 13 & 15 \\
Ester + urea & 10 & 5 & 5 & & 5 & 0 & 0 \\
2,4-D amine (1200) & 31 & 20 & 20 & & 10 & 0 & 0 \\
2,4-D amine (2400) & 48 & 28 & 40 & & 18 & 30 & 5 \\
Amine(1200)+chlorsulfuron (4) & 74 & 75 & 80 & & 23 & 35 & 0 \\
Aminopyralid (60) & 89 & 99 & 100 & & 100 & 100 & 100 \\
LSD(P<0.05) & & & & & & \\
\hline
\end{tabular}

Unfortunately the treatments that offered the best weed control also resulted in the most pasture damage, particularly to the white clover (Trifolium repens) (Table 2). However, the damage to ryegrass and white clover from the 2,4-D mixtures was not significantly different from the full rate of 2,4-D alone. Aminopyralid was extremely 
damaging to white clover, removing it completely for the duration of the trial. Damage to perennial ryegrass (Lolium perenne) was minimal in the trial with only 2,4-D plus chlorsulfuron causing damage. For the 2,4-D ester plus chlorsulfuron this was assessed as $18 \%$ and $5 \%$ for November and December respectively and no damage was observed in January. Corresponding figures for 2,4-D amine plus chlorsulfuron were 5\%,5\% and no damage.

\section{Field trial - ragwort}

The results for ragwort (Trial 2, Table 3) were similar to those from nodding thistle in that most of the herbicide spikes used with the half rate of 2,4-D showed efficacy equal to the full rate of 2,4-D and significantly better than the half rate alone. The rates of chlorsulfuron used in this trial were lower than in Trial 1 and pasture damage was considerably less. No clover damage persisted through to the January assessment, except for aminopyralid, which remained at $100 \%$. No damage to ryegrass was observed during any of the assessments.

TABLE 3: Control of ragwort ( $\%$ remaining number of ragwort plants per plot) and damage to white clover $(\%)$ from herbicide combinations applied on 28.11.06, with measurements made on 18.12.06 (Dec), 26.1.07 (Jan) and 21.2.07 (Feb).

\begin{tabular}{lccccccc}
\hline & \multicolumn{3}{c}{ Ragwort (\%) } & & \multicolumn{2}{c}{ White clover $^{1}$} \\
\cline { 2 - 3 } \cline { 6 - 7 } Treatment (rate: g ai/ha) & Dec & Jan & Feb & & Dec & Jan \\
\hline Untreated & 0 & 0 & 0 & & 0 & 0 \\
2,4-D ester (1040) & 15 & 30 & 43 & & 0 & 0 \\
2,4-D ester (2080) & 25 & 60 & 67 & & 0 & 5 \\
Ester (1040)+chlorsulfuron (1) & 58 & 75 & 75 & & 0 & 0 \\
Ester (1040)+chlorsulfuron (3) & 63 & 86 & 87 & & 0 & 8 \\
Ester (1040)+flumetsulam (20) & 48 & 46 & & 43 & & 0 & 0 \\
Ester (1040)+mesotrione (20) & 55 & 73 & & 85 & & 0 & 0 \\
Ester (1040)+aminopyralid (3) & 28 & 78 & 75 & & 12 & 23 \\
2,4-D amine (1200) & 20 & 65 & 75 & & 0 & 0 \\
2,4-D amine (2400) & 30 & 84 & 92 & & 0 & 5 \\
Amine (1200)+chlorsulfuron (3) & 70 & 94 & 95 & & 0 & 0 \\
Aminopyralid (60) & 80 & 100 & 100 & & 60 & 100 \\
LSD(P<0.05) & & & & & & \\
\hline
\end{tabular}

${ }^{1}$ No clover damage was observed during the February assessment except for aminopyralid, which remained at $100 \%$.

\section{Outdoor pot experiments - impact of stage of growth}

Results from the pot trials are presented in Table 4 (nodding thistle) and Table 5 (ragwort). These show that nodding thistle was readily killed when the plants were less than $150 \mathrm{~mm}$ diameter or about 1 month old (Table 1). After this time the efficacy began to decline, particularly for the low rates of 2,4-D. Of the treatments applied on 31 August 2007, only the high rate of 2,4-D (both formulations) plus mesotrione resulted in greater than $95 \%$ control while the high rate of 2,4-D alone and the mixture with chlorsulfuron resulted in 80-90\% control (data not presented). In the earlier assessments 2,4-D plus mesotrione performed significantly better than the other treatments, but no significant differences existed at the final assessment. This shows that the knockdown of the mesotrione mixture was significantly faster. For the treatments applied on 
29 September 2007, the 2,4-D plus mesotrione mixture again provided faster knockdown but by the time of the final assessment ( 8 weeks after treatment) there were no significant differences between the treatments and control was only $50-80 \%$ for the highest rates evaluated (data not shown). Overall, with the application rates chosen mesotrione was a superior additive to 2,4-D than chlorsulfuron for control of nodding thistle but effective control could only be achieved on plants smaller than $300 \mathrm{~mm}$ in diameter or under 3 months old with the low rates of herbicide evaluated.

TABLE 4: Visual assessment of damage (\%) to potted nodding thistle plants, planted on 9.5.07, and sprayed at four different stages of growth.

\begin{tabular}{|c|c|c|c|c|c|c|c|c|c|}
\hline \multirow[b]{2}{*}{ Treatment $^{1}$} & \multirow{2}{*}{$\begin{array}{c}\text { Rate } a i^{2} \\
(\mathrm{~g} / \mathrm{ha})\end{array}$} & \multicolumn{2}{|c|}{$5.6 .07^{3}$} & \multicolumn{2}{|c|}{$23.6 .07^{3}$} & \multicolumn{2}{|c|}{$6.7 .07^{3}$} & \multicolumn{2}{|c|}{$3.8 .07^{3}$} \\
\hline & & $4 \mathrm{Wk}^{4}$ & $12 \mathrm{Wk}$ & $4 \mathrm{Wk}$ & $10 \mathrm{Wk}$ & $4 \mathrm{Wk}$ & $11 \mathrm{Wk}$ & $4 \mathrm{Wk}$ & $10 \mathrm{Wk}$ \\
\hline \multirow[t]{3}{*}{ 2,4-D ester } & 260 & 85 & 99 & 55 & 100 & 43 & 81 & 40 & 63 \\
\hline & 520 & 93 & 100 & 63 & 100 & 55 & 100 & 50 & 99 \\
\hline & 1040 & 98 & 100 & 88 & 100 & 73 & 100 & 65 & 100 \\
\hline \multirow[t]{3}{*}{ 2,4-D amine } & 300 & 85 & 100 & 55 & 98 & 43 & 89 & 55 & 86 \\
\hline & 600 & 90 & 100 & 75 & 100 & 73 & 99 & 78 & 100 \\
\hline & 1200 & 99 & 100 & 88 & 100 & 78 & 100 & 88 & 100 \\
\hline \multirow[t]{3}{*}{ Ester+Chlor } & 130 & 95 & 100 & 48 & 55 & 38 & 45 & 58 & 78 \\
\hline & 260 & 98 & 100 & 53 & 75 & 55 & 65 & 60 & 84 \\
\hline & 520 & 100 & 100 & 85 & 100 & 50 & 78 & 68 & 86 \\
\hline \multirow[t]{3}{*}{ Amine+Chlor } & 150 & 99 & 100 & 45 & 65 & 53 & 53 & 48 & 68 \\
\hline & 300 & 99 & 100 & 55 & 70 & 58 & 70 & 60 & 80 \\
\hline & 600 & 99 & 100 & 78 & 96 & 65 & 85 & 68 & 95 \\
\hline \multirow[t]{3}{*}{ Ester+Meso } & 130 & 100 & 100 & 63 & 98 & 70 & 89 & 70 & 65 \\
\hline & 260 & 100 & 100 & 78 & 100 & 86 & 100 & 80 & 95 \\
\hline & 520 & 100 & 100 & 93 & 100 & 94 & 100 & 88 & 98 \\
\hline \multirow[t]{3}{*}{ Amine+Meso } & 150 & 100 & 100 & 73 & 100 & 68 & 65 & 68 & 63 \\
\hline & 300 & 100 & 100 & 84 & 100 & 73 & 100 & 85 & 93 \\
\hline & 600 & 100 & 100 & 96 & 100 & 81 & 100 & 93 & 100 \\
\hline Untreated & - & 0 & 0 & 0 & 0 & 0 & 0 & 0 & 0 \\
\hline $\begin{array}{l}\text { LSD } \\
(\mathrm{P}<0.05)\end{array}$ & & 4.1 & 0.5 & 12.4 & 8.6 & 10.8 & 14.0 & 15.9 & 12.2 \\
\hline
\end{tabular}

${ }^{1}$ Ester=2,4-D ester, Amine=2,4-D amine, Chlor=chlorsulfuron, Meso=mesotrione.

${ }^{2}$ Rate of chlorsulfuron was $4 \mathrm{~g}$ ai/ha, rate of mesotrione was $83 \mathrm{~g}$ ai/ha.

${ }^{3}$ Treatment date.

${ }^{4} \mathrm{Wk}=$ weeks after treatment.

Ragwort proved more difficult to control than nodding thistle, with few of the treatments achieving a 100\% kill (Table 5). Again size was a critical factor, with ragwort plants up to $120 \mathrm{~mm}$ in diameter (5 weeks old, Table 1 ) being readily controlled by most treatments. However, after this time the ragwort plants became more tolerant. Both mesotrione and chlorsulfuron combinations with 2,4-D provided faster knockdown compared to 2,4-D alone but only in a few instances was the final effect from these combinations significantly better than for the highest rate of 2,4-D alone. Results from the final treatment application on 31 October 2007 were similar to those for the previous application on 28 September 2007 in Table 5. 
TABLE 5: Visual assessment of damage (\%) to potted ragwort plants, planted on 7.6.07, and sprayed at four different stages of growth.

\begin{tabular}{|c|c|c|c|c|c|c|c|c|c|}
\hline \multirow[b]{2}{*}{ Treatment $^{1}$} & \multirow{2}{*}{$\begin{array}{c}\text { Rate } a i^{2} \\
(\mathrm{~g} / \mathrm{ha})\end{array}$} & \multicolumn{2}{|c|}{$13.7 .07^{3}$} & \multicolumn{2}{|c|}{$3.8 .07^{3}$} & \multicolumn{2}{|c|}{$24.8 .07^{3}$} & \multicolumn{2}{|c|}{$28.9 .07^{3}$} \\
\hline & & $4 \mathrm{Wk}^{4}$ & $12 \mathrm{Wk}$ & $4 \mathrm{Wk}$ & $10 \mathrm{Wk}$ & $4 \mathrm{Wk}$ & $11 \mathrm{Wk}$ & $4 \mathrm{Wk}$ & $10 \mathrm{Wk}$ \\
\hline \multirow[t]{3}{*}{ 2,4-D ester } & 260 & 48 & 95 & 58 & 78 & 60 & 75 & 30 & 60 \\
\hline & 520 & 60 & 100 & 55 & 78 & 75 & 92 & 40 & 65 \\
\hline & 1040 & 63 & 100 & 63 & 91 & 70 & 100 & 60 & 93 \\
\hline \multirow[t]{3}{*}{ 2,4-D amine } & 300 & 55 & 93 & 53 & 78 & 50 & 58 & 30 & 50 \\
\hline & 600 & 63 & 93 & 63 & 85 & 73 & 90 & 40 & 68 \\
\hline & 1200 & 68 & 100 & 60 & 93 & 80 & 95 & 70 & 92 \\
\hline \multirow[t]{3}{*}{ Ester+Chlor } & 130 & 96 & 99 & 89 & 90 & 60 & 55 & 63 & 81 \\
\hline & 260 & 100 & 100 & 100 & 97 & 83 & 90 & 70 & 90 \\
\hline & 520 & 100 & 100 & 96 & 89 & 81 & 97 & 70 & 84 \\
\hline \multirow[t]{3}{*}{ Amine + Chlor } & 150 & 99 & 80 & 94 & 97 & 79 & 95 & 60 & 85 \\
\hline & 300 & 99 & 100 & 96 & 95 & 95 & 97 & 58 & 74 \\
\hline & 600 & 100 & 100 & 98 & 99 & 73 & 91 & 68 & 84 \\
\hline \multirow[t]{3}{*}{ Ester+Meso } & 130 & 93 & 100 & 63 & 83 & 68 & 73 & 50 & 43 \\
\hline & 260 & 96 & 100 & 63 & 86 & 75 & 90 & 58 & 68 \\
\hline & 520 & 97 & 100 & 80 & 95 & 85 & 100 & 60 & 81 \\
\hline \multirow[t]{3}{*}{ Amine + Meso } & 150 & 90 & 100 & 73 & 90 & 70 & 55 & 65 & 64 \\
\hline & 300 & 96 & 100 & 75 & 98 & 85 & 80 & 65 & 80 \\
\hline & 600 & 98 & 100 & 78 & 100 & 83 & 95 & 61 & 69 \\
\hline Untreated & - & 0 & 0 & 0 & 0 & 0 & 0 & 0 & 0 \\
\hline $\operatorname{LSD}(\mathrm{P}<0.05)$ & & 10.1 & 9.2 & 18.9 & 13.5 & 21.6 & 16.9 & 13.4 & 13.4 \\
\hline
\end{tabular}

${ }^{1}$ Ester $=2,4-\mathrm{D}$ ester, Amine=2,4-D amine, Chlor=chlorsulfuron, Meso=mesotrione.

${ }^{2}$ Rate of chlorsulfuron was $4 \mathrm{~g}$ ai/ha, rate of mesotrione was $83 \mathrm{~g}$ ai/ha.

${ }^{3}$ Treatment date.

${ }^{4} \mathrm{Wk}=$ weeks after treatment.

\section{CONCLUSIONS}

These results demonstrate that the application rate of 2,4-D could be halved and effective control of both nodding thistle and ragwort still be achieved if low doses of either chlorsulfuron or mesotrione are used as additives in a treatment mix. Mesotrione would be the preferred choice as this mixture was more effective on nodding thistle and also resulted in less pasture damage. As well as being able to halve the rate of 2,4-D applied, the additives also significantly improved the speed of knockdown or brownoff of the weeds. The data presented here could also be used to more accurately match 2,4-D use rates to plant size, although, in practice, it is very rare to find naturally occurring populations of uniform size.

Both nodding thistle and ragwort have been reported as difficult to control weeds albeit for differing reasons. Multicrown ragwort plants especially are very difficult to control (Martin et al. 1986). However, as the mixtures evaluated here performed only equal to or slightly better than the higher rate of 2,4-D alone and did not perform well on the older plants in the pot trial, it is unlikely that these would be effective on multicrown ragwort plants. Nodding thistle plants in many locations in New Zealand have become resistant to the phenoxy herbicides and additives to 2,4-D have been successfully used to control 
these resistant plants (James et al. 1995), although some of these mixtures have proved quite damaging to the pasture (James et al. 1993; Rahman et al. 1993). The herbicide combinations evaluated here were not tested on phenoxy-resistant nodding thistles but due to their possible greater pasture safety this would be the logical next step.

\section{ACKNOWLEDGEMENTS}

We thank the property owners for providing trial sites; Andy Laurenson and Chris Hale, Plant Pest Officers for Environment Waikato, for their assistance with the field trials; and Mike Trolove and Erin Carney for help with the pot trials. Financial support for this project was provided by the New Zealand Foundation for Research, Science and Technology.

\section{REFERENCES}

Anon. 2002. Towards a pesticide risk reduction policy for New Zealand. Ministry for the Environment, ME number $427.68 \mathrm{pp}$.

Brodie A 1949. Low-volume nozzles. Proceedings of the Second National Weeds Conference 2: 49-54.

James TK, Rahman A, Sanders P 1993. Tolerance of white clover to some phenoxy herbicides and mixtures. Proceedings of the $46^{\text {th }}$ New Zealand Plant Protection Conference. Pp. 288-291.

James TK, Rahman A, Sanders P, Cliffe A 1995. Response of different nodding thistle (Carduus nutans) populations to herbicides. Proceedings of the $48^{\text {th }}$ New Zealand Plant Protection Conference. Pp. 252-255.

James TK, Rahman A, De Jong P 1997. Flazasulfuron for control of ragwort (Senecio jacobaea) in pasture. Proceeding of the $50^{\text {th }}$ New Zealand Plant Protection Conference. Pp. 447-452.

Manktelow D, Stevens P, Walker J, Gurnsey S, Park N, Zabkiewicz J, Teulon D, Rahman A 2005. Trends in pesticide use in New Zealand: 2004. The Horticulture and Food Research Institute of New Zealand Ltd, Auckland. 74 pp.

Martin P, Thompson A, Rahman A 1988. Spot treatment of ragwort and nodding thistle with DPX-L5300. Proceeding of the $41^{\text {st }}$ New Zealand Weed and Pest Control Conference. Pp. 223-225.

Martin P, Thompson A, Saunders AE, Rahman A 1986. Effect of plant type on the response of ragwort to rates and times of 2,4-D application. Proceedings New Zealand Weed and Pest Control Conference 39: 179-182.

Matthews LJ 1956. Chemical methods of weed control. New Zealand Department of Agriculture Bulletin No. 329.90 pp.

Muller FB 1952. Weed-killing fertiliser mixtures. Proceedings of the $5^{\text {th }}$ New Zealand Weed Control Conference. Pp. 61-68.

Rahman A, James TK, Sanders P, Nicholson K 1993. Tolerance of perennial ryegrass/white clover pastures to five sulfonylurea herbicides. Proceedings of the 14th Asian Pacific Weed Science Society Conference. Pp. 310-314.

Ward RK 1949. A review of the weed control investigations at the Soil Fertility Research Station, Hamilton. Proceedings of the Second National Weeds Conference. Pp. $5-15$. 